\title{
Analisis Kemampuan Pemecahan Masalah Pola Bilangan Ditinjau Dari Gaya Belajar
}

\section{Gusti Ayu Sinta Inastuti ${ }^{*}$, Sri Subarinah², Eka Kurniawan², Amrullah ${ }^{2}$}

\author{
${ }^{1}$ Mahasiswa Pendidikan Matematika, Universitas Mataram, Mataram \\ ${ }_{2}^{2}$ Pendidikan Matematika, Universitas Mataram, Mataram \\ *Corresponding Author e-mail: ayusintainastuti@gmail.com
}

Received: 27-01-2021; Revised: 24-03-2021; Published: 25-03-2021

\begin{abstract}
The purpose of this study was to determine eighth grade student problem-solving ability on number pattern material. This study was held academic year focused on assessing students learning styles. The methods used in this study were questionnaires, tests, and interviews. The results showed that class VIII students consisted of 26 students had visual learning styles, 24 students had auditory styles and 16 students had kinesthetic styles. Subjects taken in this study were 2 students from each learning style, then the subject was given a test to describe the number pattern material and conducted an interview. As a result, based on the analysis of the problem-solving ability stages, students with visual and auditory learning styles were able to reach the stage of understanding the question / problem, designing and choosing a solution strategy, and solving problems with a mathematical model, but have not yet reached the stage of re-checking the solutions obtained. on the contrary, Students with a kinesthetic learning style have been able to reach the stage of understanding the question / problem, but have not been able to reach the stage of designing and choosing a solution strategy, or solving problems with mathematical models, and even re-checking the solutions obtained. This shows that the problem solving ability of students with visual and auditory learning styles is better than students with kinesthetic learning styles.
\end{abstract}

Keywords: Problem Solving Ability; Learning Style; Number Patterns

\begin{abstract}
Abstrak
Tujuan dari penelitian ini adalah untuk mengetahui kemampuan pemecahan masalah pada materi pola bilangan siswa ditinjau dari gaya belajar. Metode yang digunakan dalam penelitian ini yaitu angket, tes, dan wawancara. Hasil penelitian menunjukkan siswa memiliki gaya belajar visual sebanyak 26 orang, auditorial sebanyak 24 orang dan kinestetik sebanyak 16 orang. Subjek yang diambil adalah masing - masing 2 orang dari gaya belajar yang diteliti, kemudian subjek diberikan tes uraian materi pola bilangan dan dilakukan wawancara. Berdasarkan hasil analisis tahapan kemampuan pemecahan masalah, siswa dengan gaya belajar visual dan auditorial, sudah mampu mencapai tahap memahami soal/masalah, merancang dan memilih strategi penyelesaian, dan menyelesaikan masalah dengan model matematika, namun belum mencapai tahap memeriksa kembali penyelesaian yang didapat. Siswa dengan gaya belajar kinestetik sudah mampu mencapai tahap memahami soal/masalah, namun belum mampu mencapai tahap merancang dan memilih strategi penyelesaian, menyelesaikan masalah dengan model matematika, dan memeriksa kembali penyelesaian yang didapat. Hal tersebut menunjukkan bahwa kemampuan pemecahan masalah siswa dengan gaya belajar visual dan auditorial lebih baik dibandingkan siswa dengan gaya belajar kinestetik.
\end{abstract}

Kata Kunci: Kemampuan Pemecahan Masalah; Gaya Belajar; Pola Bilangan

\section{Cara Mengutip}

Inastuti, I.A.A, Subarinah, S., Kurniawan, E., \& Amrullah (2020). Analisis kemampuan pemecahan masalah pola bilangan ditinjau dari gaya belajar. Griya Journal of Mathematics Education and Application, 1(1), 66-80. 


\section{PENDAHULUAN}

Pendidikan sangatlah penting bagi kelangsungan hidup berbangsa dan bernegara dalam upaya pembangunan dan peningkatan kualitas SDM, sesuai dengan tujuan pendidikan Negara Kesatuan Republik Indonesia tertuang pada Pembukaan UUD 1945 alenia keIV. Pendidikan inilah yang menjadi wahana dalam menemukan pengalaman dan menumbuhkan kemampuan untuk memecahkan masalah baik permasalahan yang besar maupun kecil dan sederhana dalam kehidupan sehari - hari. Matematika merupakan salah satu pelajaran penting untuk mengasah dan meningkatkan kemampuan siswa untuk memecahkan masalah. Sebagaimana Permendiknas No. 22 tahun 2006 tentang tujuan mempelajari matematika, yaitu salah satunya agar siswa memiliki kemampuan memecahkan masalah. Tercapai atau tidak tujuan tersebut, dapat dilihat berdasarkan penilaian dari hasil belajar siswa. Menurut Benjamin Bloom dalam Taxonomy Bloom bahwa perubahan hasil belajar dikelompokkan menjadi tiga yaitu (1) domain kognitif; (2) domain afektif; dan (3) domain psikomotorik. Domain kognitif menurut Taxonomy Bloom yaitu: (1) knowledge (C1); (2) comprehension (C2); (3) application (C3); (4) analysis (C4); (5) synthesis (C5); dan (6) evaluation (C6) (Wahidmurni, Mustikawan, and Ridho 2015). Didapat kesimpulan bahwa semakin tinggi kemampuan kognitif siswa maka semakin mampu siswa melakukan pemecahan masalah, begitupun sebaliknya siswa dengan kemampuan kognitif rendah akan banyak melakukan kesalahan dalam pemecahan masalah (Nafi'an 2015).

Kemampuan pemecahan masalah dalam bidang matematika merupakan suatu pendekatan pembelajaran yang berorientasi pada pengamatan dan pencarian metode kemudian mengamati permasalahan yang ada lalu pembuatan hipotesis atau dugaan sementara dan diakhir melakukan peninjauan kembali terhadap hasil yang telah dibuat sehingga dapat menyimpulkan (Nurojab and Sari 2019). Tahapan kemampuan pemecahan masalah yang digunakan dalam penelitian ini, yaitu: (1) Memahami soal/masalah, (2) Merancang dan memilih strategi dalam menyelesaikan masalah, (3) Menyelesaikan soal/masalah dengan model matematika, dan (4) Memeriksa kembali penyelesaian yang didapat. Kemampuan siswa dalam memecahkan masalah juga berkaitan dengan gaya belajar yang dimiliki, karena dengan mengetahui tipe gaya belajar yang dimiliki akan berpengaruh positif dalam hal proses belajarnya, lebih mudah dan cepat mencapai kesuksesan, sehingga gaya belajar merupakan hal yang penting dalam hidup seseorang (Gilakjani and Ahmadi 2011). Keuntungan lain yang dapat diperoleh seseorang jka mengetahui tipe gaya belajarnya, yaitu akan membantu siswa sebagai seseorang pemecah masalah yang efektif.

Gaya belajar merupakan cara untuk melakukan kegiatan berfikir, berproses dan mengerti terhadap informasi yang dirasa paling disukai, nyaman terhadap diri sendiri, dan berbeda dengan individu lainnya (Filayati, Novianti, and Suriyah 2019). Gaya belajar yang dimaksud dalam penelitian ini adalah gaya belajar menurut Bobi De Porter dan Mike Hernacki yang terbagi menjadi tiga yaitu gaya belajar visual, auditorial, dan kinestetik. Siswa dengan gaya belajar visual mempunyai karakteristik positif antara lain: (1) lebih suka belajar dengan cara melihat; (2) membaca dengan cepat dan tekun; 
(3) mudah mengingat dengan asosiasi visual; (4) tidak terganggu saat duduk ditempat ramai dan bising (Amin and Sudirman 2016). Siswa yang belajar dengan cara auditory (mendengar) memiliki karakteristik seperti: (1) suka dengan forum debat dan diskusi; (2) lebih dapat menerima informasi verbal disbanding tulisan; (3) senang mendengarkan berita; (4) suka berbicara dengan orang lain; (5) suka musik dan bernyanyi; (6) tidak mudah mengerti mengenai peta, diagram atau grafik; (7) membaca dengan pelan; (8) tidak dapat diam dengan waktu yang lama; (9) cepat mengingat nama (Ldpride n.d.). Siswa yang belajar dengan cara kinestetik memiliki karakteristik seperti: (1) suka dengan gerakan, pengalaman dan penemuan; (2) lebih mudah mengingat konsep yang diperagakan; (3) menggunakan gerakan tangan saat menjelaskan dan berbicara cepat; (4) bagus dalam olahraga, menari ataupun gerakan tubuh lainnya; (5) suka memainkan benda agar berbunyi saat belajar ataupun bekerja (Ldpride n.d.). Materi pola bilangan penting untuk diasah kemampuan pemecahan masalahnya, karena selalu muncul dalam kisi - kisi soal Tes Intelegensi Umum (TIU) pada tes SKD CPNS (Debora n.d.) dan juga dalam pelaksanaan pembelajaran, masih ada kesalahan proses penyelesaian pada materi pola bilangan.

Berdasarkan pemaparan diatas tujuan penelitian ini adalah untuk mengetahui kemampuan pemecahan masalah pada materi pola bilangan ditinjau dari gaya belajar. Diharapkan hasil penelitian ini dapat dijadikan sebagai informasi tambahan mengenai gambaran kemampuan pemecahan masalah dan gaya belajar pada siswa, khususnya guru untuk menentukan metode pembelajaran di kelas. Bagi peneliti selanjutnya dapat menjadikan penelitian ini refrensi dalam melakukan penelitian yang berkaitan dengan analisis kemampuan pemecahan masalah siswa ditinjau dari gaya belajar.

\section{METODE}

Jenis penelitian ini adalah penelitian deskriptif dengan pendekatan kualitatif. Pendeskripsian kualitatif pada penelitian ini dilakukan dengan memberikan gambaran atau mendeskripsikan tentang kemampuan pemecahan masalah pada materi pola bilangan dari masing-masing gaya belajar. Waktu dan tempat pelaksanaan penelitian ini adalah pada semester ganjil tahun ajaran 2020/2021. Pemberian angket gaya belajar terbatas pada siswa yang dapat melakukan pembelajaran mandiri aktif secara daring, dikarenakan situasi dan kondisi selama pandemi, kemudian pemilihan subjek penelitian dilakukan berdasarkan angket gaya belajar, artinya dari masing - masing gaya belajar diambil 2 siswa, sehingga jumlah subjek sebanyak 6 orang dengan teknik acak dan atas pertimbangan guru serta kesediaan subjek.

Pada penelitian ini, peneliti merupakan instrument kunci atau peneliti kualitatif sebagai human instrument, yang berfungsi menetapkan fokus penelitian, memilih subyek sebagai responden, melakukan pengumpulan data, menguji kualitas data, mengalisis data, mentafsirkan data, dan menarik kesimpulan. Selain itu pada penelitian ini digunakan instrumen tambahan, antara lain soal tes sebanyak 5 soal dengan indikator yang sesuai pada materi pola bilangan, non tes berupa adalah angket tertutup sebanyak 28 pernyataan dengan alternatif - alternatif jawaban yang telah disediakan dan pedoman wawancara. Pengujian kevalidan instrumen tes dan prosedur wawancara 
menggunakan validasi isi oleh 2 dosen ahli dan 1 orang guru mata pelajaran matematika di sekolah tempat penelitian dan untuk pengujian instrumen non tes berupa angket menggunakan uji empiris dengan rumus korelasi product moment pearson untuk menguji kevalidan dan uji reliabilitas angket menggunakan rumus alpha. Analisis data dalam penelitian ini menggunakan analisis data kualitatif menurut Miles and Huberman, yaitu data reduction (reduksi data), data display (penyajian data), dan conclusion drawing/verification (penarikan kesimpulan) (Sugiono 2020) dan analisis data kuantitatif untuk tes uraian materi pola bilangan dan pengelompokkan gaya belajar siswa

\section{HASIL DAN PEMBAHASAN}

Berdasarkan pemberian angket gaya belajar, kemudian dipilih subjek penelitian yang mewakili masing - masing kelompok gaya belajar, yaitu siswa dengan gaya belajar visual, auditorial, dan Pada soal nomor 1 siswa dengan gaya belajar kinestetik (S59), dalam melakukan tahap memahami soal/masalah, sudah dapat membedakan informasi yang diketahui dan ditanyakan, dapat terlihat bahwa siswa (S59) menuliskan pola bilangan yang ada pada soal/masalah pada kolom diketahui dan menuliskan hal yang ditanyakan pada kolom diketahui.

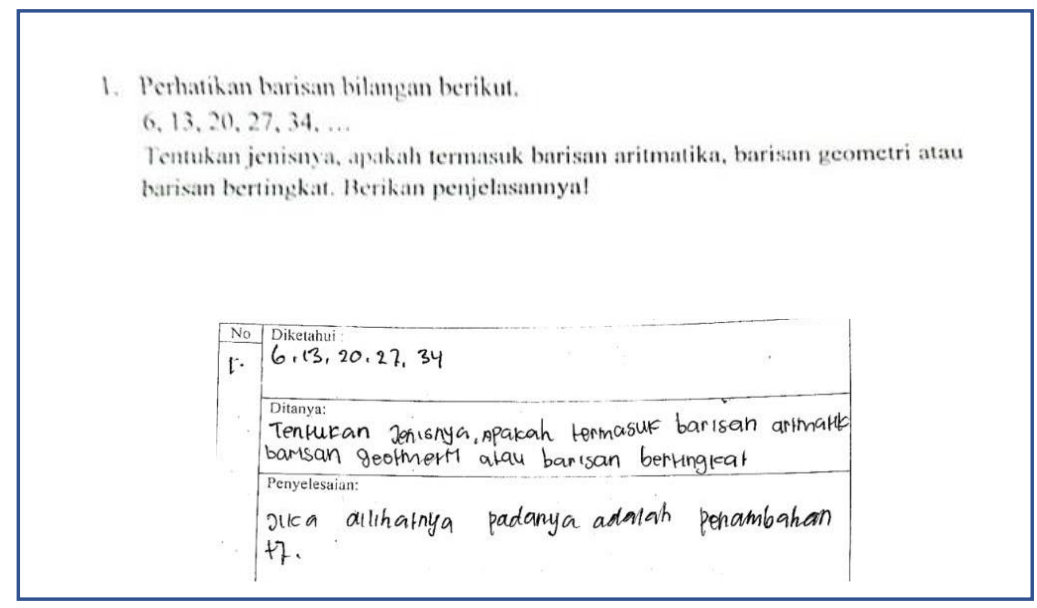

Gambar 1. Jawaban Siswa

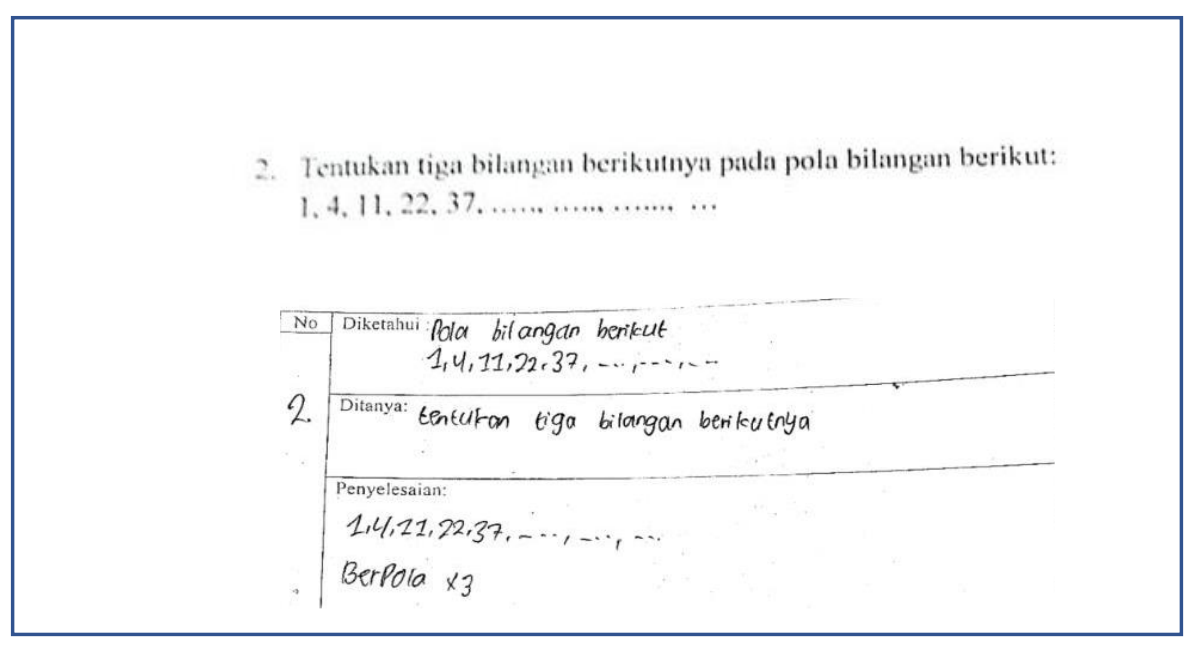

Gambar 2. Jawaban Nomor 2 
Kemudian untuk tahap memilih dan merancang strategi penyelesaian, siswa (S59) langsung menuliskan angka yang selalu bertambah pada pola bilangan yang tersedia. Pada hal ini siswa (S59) belum melakukan tahapan perencanaan yang baik dan belum mampu membuat suatu strategi yang jelas untuk menyelesaiakn soal/masalah, walaupun tujuan yang ingin dicapai sudah benar.

Pada soal nomor 2, siswa dengan gaya belajar kinestetik (S56) dalam melakukan tahap memahami soal/masalah, sudah dapat membedakan informasi yang diketahui dan ditanyakan, dapat terlihat bahwa siswa (S56) menuliskan pola bilangan pada kolom diketahui dan menuliskan hal yang ditanyakan pada kolom ditanya, namun siswa (S56) hanya menuliskan ulang soal pada informasi ditanyakan tanpa mengubahnya menjadi kalimat tanya. Kemudian untuk tahap memilih dan merancang strategi penyelesaian, siswa (S56) langsung menuliskan pola yang selalu berubah yaitu perkalian tiga. Pada hal ini siswa S56 melakukan tahap memilih dan merancang strategi yang tidak tepat dan tidak sesuai dan belum mampu membuat suatu strategi yang jelas untuk menyelesaikan soal/masalah, sehingga menyebabkan siswa dengan gaya belajar kinestetik (S56), tidak mampu melanjutkan tahapan berikutnya.

Kemudian, pada soal nomor 2, siswa dengan gaya belajar visual (S50) dalam melakukan tahap memahami soal/masalah, sudah dapat membedakan informasi yang diketahui dan ditanyakan, dapat terlihat bahwa siswa (S50) menuliskan pola bilangan pada kolom diketahui dan menuliskan hal yang ditanyakan pada kolom ditanya, namun siswa visual (S50) juga hanya menuliskan ulang soal, pada informasi ditanyakan tanpa mengubahnya menjadi kalimat tanya. Kemudian untuk tahap memilih dan merancang strategi penyelesaian, terlihat jawaban siswa (S50) sudah mampu memilih dan merancang strategi penyelesaian dengan tepat dan lengkap, yaitu membuat suatu pola bertingkat pada barisan bilangan. Kemudian untuk tahap menyelesaikan soal dengan model matematika, terlihat siswa visual (S50) dapat menentukan tiga bilangan selanjutnya berdasarkan pola bilangan bertingkat yang ditemukan, dengan cara menjumlahkan bilangan sebelumnya untuk menemukan bilangan selanjutnya. Dan untuk tahap memeriksa kembali penyelesaian yang didapat siswa visual (S50) tidak melakukan pemeriksaan kembali, untuk menginterprestasi penyelesaian yang didapat dengan soal/masalah awal, karena siswa beranggapan selalu menemukan penyelesaian yang tepat. 


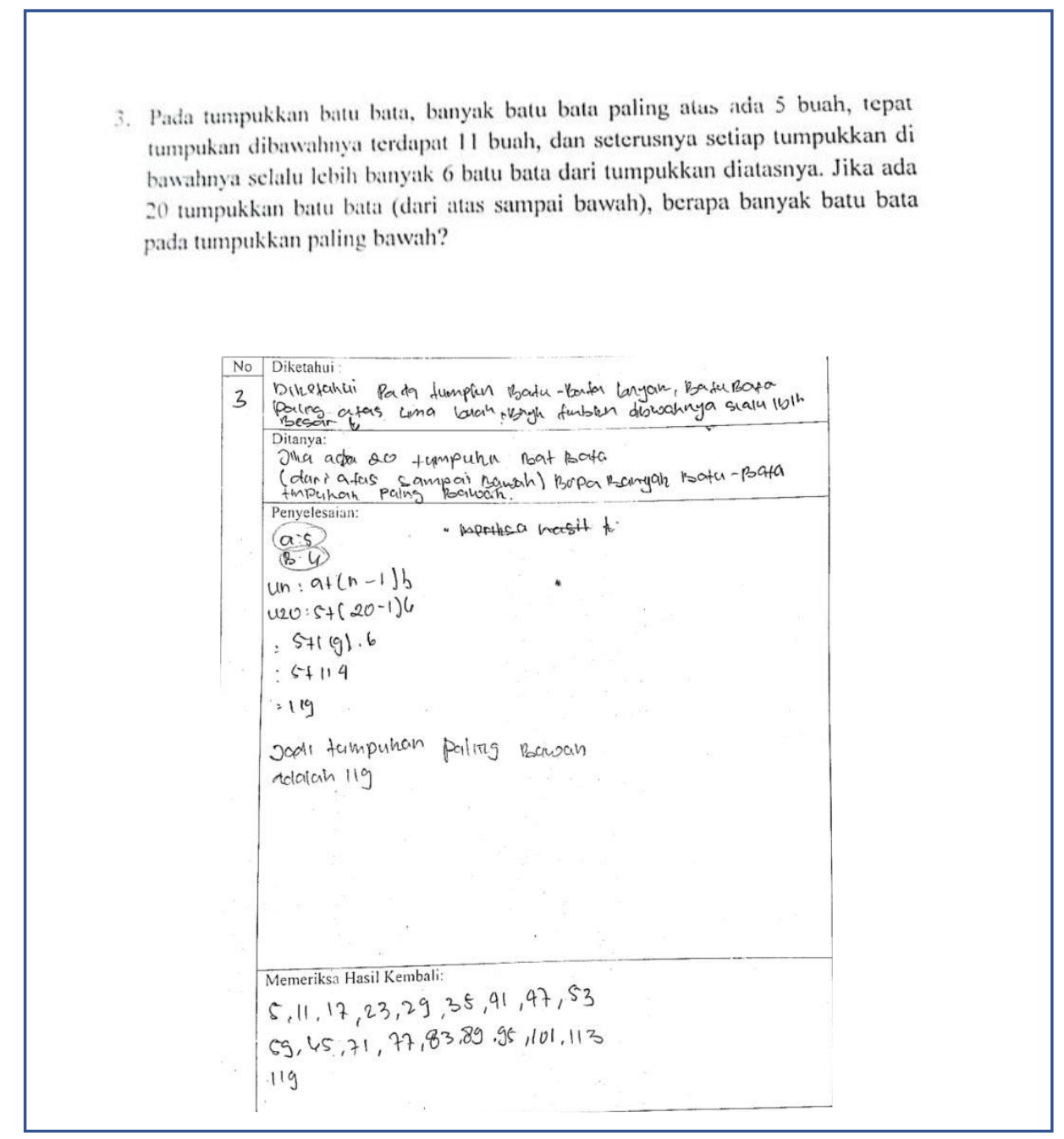

Gambar 3. Jawaban Nomor 3

Pada soal nomor 3, siswa dengan gaya belajar auditorial (S62) dalam melakukan tahap memahami soal/masalah, sudah dapat menuliskan seluruh informasi pada soal/masalah, namun terdapat informasi diketahui yang dituliskan pada kolom ditanya. Kemudian untuk tahap memilih dan merancang strategi penyelesaian, terlihat jawaban siswa (S62) sudah mampu memilih dan merancang strategi penyelesaian dengan menggunakan suatu aplikasi rumus barisan aritmatika. Namun masih terdapat satu rancangan yang belum ditulis, yaitu banyaknya suatu pola yang diketahui dari soal/masalah. Kemudian untuk tahap menyelesaikan soal dengan model matematika, siswa auditorial (S62) sudah dapat menentukan banyaknya batu - bata pada tumpukan ke-20, menggunakan langkah - langkah penyelesaian dengan model matematika dan mensubstitusikan bilangan dengan benar. Serta untuk tahap memeriksa kembali penyelesaian yang didapat siswa auditorial (S62), melakukan pemeriksaan kembali dengan menggunakan cara lainnya dalam menyelesaiakan soal/masalah, dan masih belum melakukan interprestasi penyelesaian yang didapat dengan soal/masalah awal. 


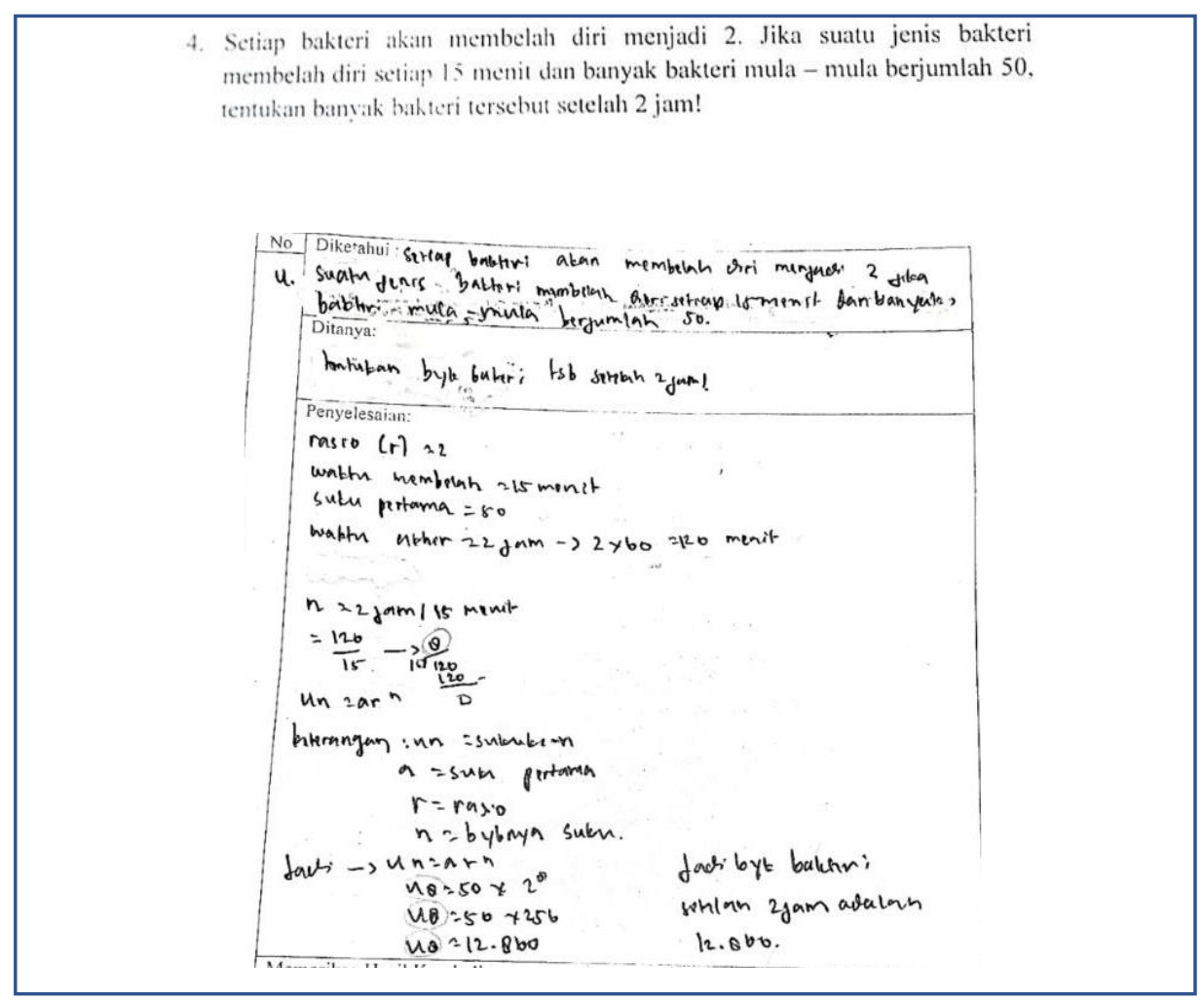

Gambar 4. Jawaban Nomor 4

Pada soal nomor 4, siswa dengan gaya belajar auditorial (S47) dalam melakukan tahap memahami soal/masalah, sudah dapat membedakan informasi yang diketahui dan ditanyakan, dapat terlihat bahwa siswa (S47) menuliskan pola bilangan pada kolom diketahui dan menuliskan hal yang ditanyakan pada kolom ditanya, namun siswa auditorial (S47) masih terdapat informasi yang belum dituliskan dan juga hanya menuliskan ulang soal, pada informasi ditanyakan tanpa mengubahnya menjadi kalimat tanya. Kemudian untuk tahap memilih dan merancang strategi penyelesaian, terlihat jawaban siswa (S47) menuliskan kembali hal - hal yang diperoleh pada tahap memahami soal/ masalah dengan lengkap dan pada tahap ini siswa sudah mampu memilih dan merancang strategi penyelesaian dengan tepat dan lengkap, yaitu mencari banyaknya pembelahan yang terjadi pada bakteri di suatu waktu tertentu, untuk digunakan pada rumus barisan geometri. Kemudian untuk tahap menyelesaikan soal dengan model matematika, terlihat siswa auditorial (S47) dapat menentukan banyaknya bakteri yang terbentuk pada selang waktu 2 jam dengan mensubtitusikan bilangan ke dalam rumus yang dipilih. Dan untuk tahap memeriksa kembali penyelesaian yang didapat siswa auditorial (S47) tidak melakukan pemeriksaan kembali, untuk menginterprestasi penyelesaian yang didapat dengan soal/masalah awal.

Pada soal nomor 4, siswa dengan gaya belajar auditorial (S47) dalam melakukan tahap memahami soal/masalah, sudah dapat membedakan informasi yang diketahui dan ditanyakan, dapat terlihat bahwa siswa (S47) menuliskan pola bilangan pada kolom diketahui dan menuliskan hal yang ditanyakan pada kolom ditanya, namun siswa auditorial (S47) masih terdapat informasi yang belum dituliskan dan juga hanya 
menuliskan ulang soal, pada informasi ditanyakan tanpa mengubahnya menjadi kalimat tanya. Kemudian untuk tahap memilih dan merancang strategi penyelesaian, terlihat jawaban siswa (S47) menuliskan kembali hal - hal yang diperoleh pada tahap memahami soal/ masalah dengan lengkap dan pada tahap ini siswa sudah mampu memilih dan merancang strategi penyelesaian dengan tepat dan lengkap, yaitu mencari banyaknya pembelahan yang terjadi pada bakteri di suatu waktu tertentu, untuk digunakan pada rumus barisan geometri. Kemudian untuk tahap menyelesaikan soal dengan model matematika, terlihat siswa auditorial (S47) dapat menentukan banyaknya bakteri yang terbentuk pada selang waktu 2 jam dengan mensubtitusikan bilangan ke dalam rumus yang dipilih. Dan untuk tahap memeriksa kembali penyelesaian yang didapat siswa auditorial (S47) tidak melakukan pemeriksaan kembali, untuk menginterprestasi penyelesaian yang didapat dengan soal/masalah awal.

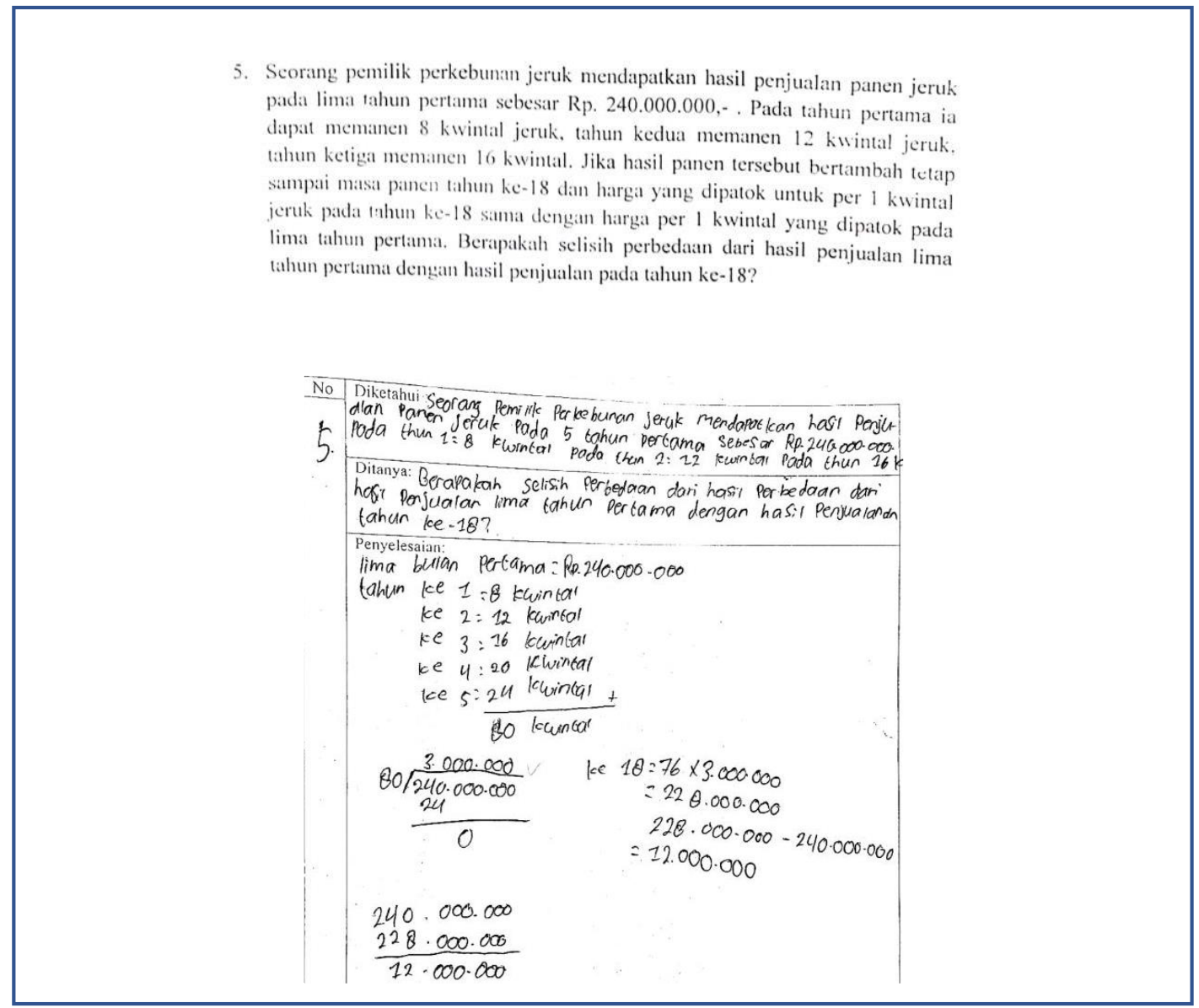

Gambar 5. Jawaban Nomor 5

Pada soal nomor 5, siswa dengan gaya belajar visual (S51) dalam melakukan tahap memahami soal/masalah, sudah dapat membedakan informasi yang diketahui dan ditanyakan, namun siswa visual (S51) masih kurang menuliskan informasi diketahui dan juga hanya menuliskan ulang soal, pada informasi ditanyakan tanpa mengubahnya menjadi model matematika. Kemudian untuk tahap memilih dan merancang strategi penyelesaian, terlihat jawaban siswa (S51) sudah mampu memilih dan merancang strategi penyelesaian dengan tepat dan lengkap, yaitu menentukan terlebih dahulu perolehan uang pada penjualan lima tahun pertama pada soal/masalah. Kemudian untuk 
tahap menyelesaikan soal dengan model matematika, terlihat siswa visual (S51) dapat menggunakan langkah - langkah penyelesaian dengan menentukan perolehan uang yang diperoleh pada tahun ke-18 dan menentukan selisih dari penjualan. Dan untuk tahap memeriksa kembali penyelesaian yang didapat siswa visual (S51) tidak melakukan pemeriksaan kembali, untuk menginterprestasi penyelesaian yang didapat dengan soal/masalah awal.

Tabel 1. Hasil Tes Kemampuan Pemecahan Masalah

\begin{tabular}{|c|c|c|c|}
\hline \multirow[t]{2}{*}{$\begin{array}{l}\text { Gaya } \\
\text { Belajar }\end{array}$} & \multicolumn{3}{|c|}{$\begin{array}{l}\text { Persentase Jawaban Benar pada Tiap - Tiap } \\
\text { Indikator Kemampuan Pemecahan Masalah }\end{array}$} \\
\hline & Visual & Auditorial & Kinestetik \\
\hline Memahami soal/masalah & $80 \%$ & $80 \%$ & $83,33 \%$ \\
\hline $\begin{array}{l}\text { Merancang dan memilih strategi dalam } \\
\text { menyelesaikan soal/masalah }\end{array}$ & $77 \%$ & $76,67 \%$ & $43,33 \%$ \\
\hline $\begin{array}{l}\text { Menyelesaikan soal/masalah dengan model } \\
\text { matematika }\end{array}$ & $63 \%$ & $63,33 \%$ & $30 \%$ \\
\hline $\begin{array}{l}\text { Memeriksa kembali penyelesaian yang } \\
\text { didapat }\end{array}$ & $0 \%$ & $10 \%$ & $0 \%$ \\
\hline Kemampuan Pemecahan Masalah & $55 \%$ & $58 \%$ & $39 \%$ \\
\hline
\end{tabular}

Sumber: hasil jawaban tes materi pola bilangan pada subjek penelitian.

Adapun deskripsi kemampuan pemecahan masalah pada materi pola bilangan ditinjau dari gaya belajar adalah sebagai berikut:

\section{Kemampuan yang Diperoleh Siswa dengan Gaya Belajar Visual}

Dalam proses pengerjaan pada tahap ini, siswa dengan gaya belajar visual sudah dapat menuliskan informasi mengenai apa yang diketahui dan ditanyakan pada soal, walaupun pada beberapa soal masih kurang lengkap dalam penulisan informasi. Kaitannya dengan tingkatan kognitif berdasarkan Taxonomy Bloom, siswa mampu mencapai tingkatan C1 dan C2 yaitu mengingat materi awal dengan dapat membedakan informasi yang diketahui dan ditanyakan serta mampu memahami soal. Siswa dengan gaya belajar visual pada saat membaca soal tidak mengeluarkan suara yang keras, membaca dengan teliti, dan menjawab dengan jawaban singkat selama proses wawancara, kemudian mampu menyebutkan dan membedakan informasi yang diketahui dan ditanya pada semua soal.Sesuai dengan hasil penelitian, bahwa subjek visual dapat menyebutkan apa yang diketahui dan ditanyakan setelah subjek membaca soal dengan keras dan memberi tanda pada soal dan setelah dilakukan triangulasi teknik pada data tertulis dan dikorfirmasi pada saat wawancara disimpulkan subjek dengan gaya belajar visual memiliki kemampuan pemahaman soal yang baik(Argarini 2018).

Pada tahap merancang dan memilih strategi penyelesaian, siswa sudah dapat merancang dan memilih strategi penyelesaian, walaupun beberapa perencanaan kurang tepat dan lengkap. Sejalan dengan hasil penelitian, bahwa dalam menjawab soal siswa visual sudah memiliki ide yang tepat, namun kurang teliti selama proses perhitungan, sehingga argument siswa visual dalam mengerjakan soal yang diberikan hampir benar hanya saja ketelitian yang kurang berdampak pada argument yang kurang tepat (Ridwan 2017). 
Tahapan ini juga berkaitan dengan kemampuan kognitif yang dimiliki siswa bergaya belajar visual, yang telah mampu mencapai tingkatan C3 dalam tingkatan kognitif berdasarkan Taxonomy Bloom, yaitu mampu menerapkan atau mengaplikasikan rumus yang diketahui dan dipahami pada soal. Hal ini sejalan dengan hasil penelitian yang didapatkan, bahwa pada tahap ini subjek dengan gaya belajar visual dalam menyelesaikan soal dengan benar telah mampu memberikan rumus atau cara penyelesaian, sehingga pada tahap ini terindikasi memiliki perencanaan sudah baik (Argarini 2018).

Pada tahap menyelesaikan soal/masalah dengan model matematika, siswa dengan gaya belajar visual telah mampu menggunakan model matematika untuk menyelesaikan soal/masalah. Dalam kaitannya dengan tingkatan kognitif berdasarkan Taxonomy Bloom, siswa pada tahap ini, telah mampu mencapai tingkatan C4 dan C5 yaitu mampu menganalisis atau merumuskan suatu masalah pada soal dan mensintesis pengetahuan yang dimiliki atau merancang model penyelesaian masalah pada soal. Berbeda dengan hasil penelitian, bahwa pada tahap pelaksanaan rencana subjek visual kurang memunculkan kemampuannya, walaupun sudah menyelesaikan masalah dengan rencana yang diajukan pada tahap kedua, namun masih terdapat kesalahan dalam pengoperasian perkalian (Argarini 2018).

Tahap memeriksa kembali hasil yang diperoleh, siswa dengan gaya belajar visual tidak dapat menggunakan cara apapun dalam memeriksa kembali penyelesaian yang didapat (tidak ada usaha). Kaitannya dengan tingkatan kognitif berdasarkan Taxonomy Bloom, diketahui siswa gaya belajar visual belum mampu mencapai tingkatan C6 yaitu mengevaluasi atau memberikan pertimbangan terhadap permasalahan pada soal. Berikut cuplikan jawaban siswa gaya belajar visual pada tahap memeriksa kembali penyelesaian yang didapat, yaitu:

...S50: "cuman diorek - orek ulang kak dari soalnya itu"

...S51: "iya yakin, cuman ngecek dari awal aja, periksa yang udah ditulis aja, cek biasa"...

Berdasarkan hasil wawancara, terlihat bahwa pada tahap ini, siswa gaya belajar visual sudah yakin dengan hasil yang diperoleh dan tidak memiliki cara apapun untuk melakukan interprestasi penyelesaian yang didapat dengan masalah awal pada soal, melainkan hanya memeriksa ulang jawaban dengan pengerjaan ulang. Hal ini sejalan dengan hasil yang diperoleh pada penelitian, yaitu subjek visual tidak memiliki kemampuan melihat kembali jawaban, karena pada tahap ini subjek visual tidak melakukan langkah apapun dalam prosedur pengecekan jawaban ulang (Argarini 2018).

\section{Kemampuan yang Diperoleh Siswa dengan Gaya Belajar Auditorial}

Pada tahap memahami soal/masalah, siswa dengan gaya belajar auditorial, sudah mampu membedakan informasi diketahui dan ditanyakan pada soal. Kaitannya dengan tingkatan kognitif Taxonomy Bloom tingkatan C1 dan C2 yaitu mengingat materi awal dengan dapat membedakan informasi yang diketahui dan ditanyakan serta mampu 
memahami soal. Hal ini sejalan dengan hasil penelitian, yakni subjek dengan gaya belajar auditorial mampu memahami maksud dari soal yang diberikan karena dalam jawaban tertulis dan wawancara subjek mampu menyebutkan apa yang diketahui dan apa yang ditanyakan dengan suara pelan (Argarini 2018).

Pada tahap merancang dan memilih strategi penyelesaian, siswa telah mampu merancang dan memilih strategi penyelesaian pada soal/masalah, walaupun ada beberapa perencanaan dan strategi kurang lengkap. Berkaitan dengan Taxonomy Bloom, siswa gaya belajar auditorial mampu menerapkan atau mengaplikasikan rumus yang diketahui dan dipahami dari soal pada tingkatan C3. Sama seperti hasil penelitian yang diperoleh, bahwa subjek auditorial mampu menentukan cara penyelesaian dalam penyelesaian soal pada tahap perencanaan (Argarini 2018).

Tahap menyelesaikan soal/masalah dengan model matematika, siswa dengan gaya belajar auditorial, dalam kaitannya dengan tingkatan kognitif berdasarkan Taxonomy Bloom, siswa pada tahap ini, telah mampu mencapai tingkatan $\mathrm{C} 4$ dan $\mathrm{C} 5$ yaitu mampu menganalisis atau merumuskan suatu masalah pada soal dan mensintesis pengetahuan yang dimiliki atau merancang model penyelesaian masalah pada soal. Sejalan dengan hasil yang diperoleh, bahwa subjek auditorial dalam tahap pelaksanaan rencana masuk kategori baik, karena telah mampu menyelesaikan soal dengan menggunakan cara atau rumus yang direncakan sebelumnya dan juga mampu memproses jawaban tanpa muncul kesalahan dalam perhitungan (Argarini 2018).

Tahap memeriksa kembali hasil yang didapat, kaitannya dengan tingkatan kognitif berdasarkan Taxonomy Bloom, diketahui siswa gaya belajar auditorial, belum mampu mencapai tingkatan C6 yaitu mengevaluasi atau memberikan pertimbangan terhadap permasalahan pada soal. Berikut cuplikan jawaban siswa gaya belajar auditorial pada tahap memeriksa kembali penyelesaian yang didapat, yaitu:

...S47: "cuman ngecek biasa, kerjain di tempat lain ulang - ulang gitu kak"

...S62: "cuman tak itung ulang aja kak"

Terlihat pada hasil wawancara, siswa gaya belajar auditorial menjelaskan bahwa pengecekan yang dilakukan hanya dengan menghitung ulang penyelesaian yang didapat, tanpa melakukan langkah interprestasi penyelesaian dengan masalah awal. Berbeda dengan hasil penelitian yang diperoleh, bahwa subjek auditorial telah terbiasa melakukan tahap pengecekan kembali jawaban yang didapat, tercermin dari hasil wawancara yang memberikan informasi tanpa ditanya, sehingga disimpulkan pada tahap melihat kembali, subjek auditorial telah melakukannya (Argarini 2018).

Dengan demikian dapat dilihat kemampuan pemecahan masalah siswa dengan gaya belajar visual dan auditorial tidak jauh berbeda. Hal ini tidak didukung oleh hasil penelitian yang menyatakan bahwa, hasil belajar matematika siswa dengan gaya belajar auditorial lebih bagus dibanding dengan gaya belajar visual maupun kinestetik. Tingkatan kemampuan pemecahan masalah yang mampu dicapai siswa ditinjau dari 
gaya belajar dalam penelitian ini, juga tidak terlepas dari kesalahan yang dilakukan oleh masing - masing individu, seperti kesalahan dalam mensubstitusikan bilangan hingga pengoperasian hitungan. Berdasarkan kesimpulan yang diperoleh, bahwa siswa melakukan kesalahan paling tinggi pada tahap penulisan jawaban dengan persentase $78 \%$, kemudian kesalahan transformasi sebesar 49\%, selanjutnya kesalahan memahami soal 44\% dan kesalahan keterampilan proses sebesar 29\% (Fitri, Subarinah, and Turmuzi 2019). Sama halnya dengan hasil penelitian, bahwa siswa melakukan kesalahan sangat tinggi pada tahap penulisan jawaban dengan persentase sebesar 83,70\%, kemudian kesalahan memahami sebesar 55,56\%, selanjutnya kesalahan membaca dan keselahan transformasi sebesar 17,78\% (Islamiyah, Prayitno, and Amrullah 2018).

\section{Kemampuan yang Diperoleh Siswa dengan Gaya Belajar Auditorial}

Dalam proses pada tahap memahami soal/masalah, siswa dengan gaya belajar kinestetik, sudah mampu membedakan informasi diketahui dan ditanyakan pada soal. Kaitannya dengan tingkatan kognitif Taxonomy Bloom tingkatan $\mathrm{C} 1$ dan $\mathrm{C} 2$ yaitu mengingat materi awal dengan dapat membedakan informasi yang diketahui dan ditanyakan serta mampu memahami soal. Pada tahap merancang dan memilih strategi penyelesaian, siswa belum dapat menunjukkan suatu rancangan ataupun strategi yang digunakan dalam menentukan langkah penyelesaian soal/masalah dengan, karena siswa dengan gaya belajar kinestetik pada seluruh perencanaan dan strategi kurang tepat dan lengkap. Berkaitan dengan Taxonomy Bloom, siswa gaya belajar kinestetik belum mampu menerapkan atau mengaplikasikan rumus yang diketahui dan dipahami dari soal pada tingkatan C3.

...S59 : "belajar dari classroom tapi kadang kurang paham juga karna sedikit penjelasan dan cuma tahan sekitar dua menitan kalau belajar lewat hp hehe"

...S56: "belajar dari video itupun cuman sekilas saya belajarnya, jadi suka gak ngerti mau pake rumus yang mana, saya lebih suka dijelasin langsung sama buguru dipapan tulis biar saya juga bisa coba langsung soal yang dikasi pas belajar di sekolah"...

Berdasarkan hasil wawancara dengan siswa gaya belajar kinestetik, terlihat pada jawaban siswa yang merasa kesulitan untuk belajar melalui dari, karena lebih suka memcoba langsung. Berbeda dengan kesimpulan yang diperoleh dalam penelitian, bahwa siswa dengan gaya belajar kinestetik pada indikator mengaplikasikan lingkaran pada sebuah gambar mampu mencapai kemampuan kognitif tingkat mengaplikasikan (C3)(Vidayanti and Kurniati 2017). Hal ini dapat dikarenakan pada masa pandemi siswa dengan gaya belajar kinestetik kurang dapat melakukan latihan soal secara langsung setelah mendapat penjelasan guru.

Tahap menyelesaikan soal/masalah dengan model matematika, siswa dengan gaya belajar kinestetik, dalam kaitannya dengan tingkatan kognitif berdasarkan Taxonomy Bloom, siswa pada tahap ini, belum mampu mencapai tingkatan C4 dan C5 yaitu mampu menganalisis atau merumuskan suatu masalah pada soal dan mensintesis pengetahuan yang dimiliki atau merancang model penyelesaian masalah pada soal. Hasil yang 
diperoleh ini tidak sesuai dengan kesimpulan dalam penelitian yang dilakukan, bahwa siswa dengan gaya belajar kinestetik melakukan kesalahan paling sedikit yaitu hanya kesalahan hasil (Vidayanti and Kurniati 2017).

Tahap memeriksa kembali hasil yang diperoleh, siswa dengan gaya belajar kinestetik tidak dapat menggunakan cara apapun dalam memeriksa kembali penyelesaian yang didapat (tidak ada usaha), kaitannya dengan tingkatan kognitif berdasarkan Taxonomy Bloom, diketahui siswa gaya belajar kinestetik belum mampu mencapai tingkatan C6 yaitu mengevaluasi atau memberikan pertimbangan terhadap permasalahan pada soal. Sesuai dengan kesimpulan yang diperoleh pada penelitian, bahwa kemampuan siswa pada indikator menyimpulkan atau pengecekan kembali jawaban masih sangat rendah, sehingga dapat berpengaruh pada penyelesaian model matematika, karena kesalahan yang ada tidak dapat dicek kembali (Nurhayati and Zanthy 2018). Hal ini sesuai dengan hasil penelitian yang, bahwa hasil belajar matematika siswa yang memiliki gaya belajar kinestetik lebih rendah dibandingkan hasil belajar matematika siswa yang memiliki gaya belajar visual dan auditoria (Anas and Munir 2016). Hasil ini memperlihatkan bahwa siswa gaya belajar kinestetik lemah pada materi pola bilangan. Sejalan kesimpulan yang diperoleh, bahwa mahasiswa dengan kemampuan matematika rendah tidak mampu menggeneralisasi suatu pola, ini terkait dengan membangun pola yang berkaitan dengan pola sebelumnya, bukan hanya menggunakan rumus yang sudah ada (Subarinah, Hikmah, and Azmi n.d.).

\section{PENUTUP}

Berdasarkan hasil penelitian, pembahasan diatas dan mengacu pada tujuan penelitian, maka diperoleh bahwa kemampuan pemecahan masalah siswa materi pola bilangan pada siswa dengan gaya belajar visual adalah mampu memahami soal/masalah dengan membedakan informasi yang diketahui dan ditanyakan pada soal/masalah, mampu merancang dan memilih strategi penyelesaian, mampu menyelesaikan soal/masalah dengan model matematika, namun belum mampu mencapai tahap memeriksa kembali penyelesaian yang didapat, sehingga mencapai persentase sebesar 55\% dan termasuk kategori penilaian penguasaan sedang. Pada siswa dengan gaya belajar auditorial adalah mampu memahami soal/masalah dengan membedakan informasi yang diketahui dan ditanyakan pada soal/masalah, mampu merancang dan memilih strategi penyelesaian, mampu menyelesaikan soal/masalah dengan model matematika, dan namun belum mampu mencapai tahap memeriksa kembali penyelesaian yang didapat, sehingga mencapai persentase sebesar 58\% dengan jumlah perolehan skor jawaban benar yaitu sebesar 69 dan termasuk kategori penilaian penguasaan sedang. Maka, dapat dilihat kemampuan pemecahan masalah siswa bergaya belajar auditorial tidak memiliki perbedaan yang signifikan dengan kemampuan pemecahan masalah siswa bergaya belajar visual. Pada siswa dengan gaya belajar kinestetik adalah hanya mampu memahami soal/masalah dengan membedakan informasi yang diketahui dan ditanyakan pada soal/masalah, dan belum mampu mencapai tahap kemampuan pemecahan masalah selanjutnya, yaitu merancang dan memilih strategi penyelesaian, menyelesaikan soal/masalah dengan model matematika, dan memeriksa kembali penyelesaian yang 
diperoleh, sehingga hanya mencapai persentase sebesar $39 \%$ dan kategori penilaian penguasaan rendah.

Penelitian ini diharapkan dapat membantu guru untuk mengetahui capaian kemampuan pemecahan masalah dan perbedaan gaya belajar pada siswa, agar nantinya dapat mengajarkan tahapan penyelesaian soal/masalah serta menggunakan media pembelajaran yang dapat mencakup ketiga gaya belajar, seperti video pembelajaran yang dapat merangsang penglihatan, pendengaran dan kinestetik siswa. Siswa juga dapat melakukan pembelajarn mandiri sesuai gaya belajar yang dimiliki, selama masa pandemi dan untuk peneliti selanjutnya dapat mengembangkan penelitian serupa pada subjek penelitian dengan tipe gaya belajar kombinasi dan dapat mengembangkan soal tes kemampuan pemecahan masalah yang lebih bervariasi.

\section{REFERENSI}

Amin, Alimah, and Siti Partini Sudirman. 2016. "Perbedaan Prestasi Belajar Matematika Siswa Ditinjau Dari Gaya Belajar Dan Model Pembelajaran.” Jurnal Prima Edukasia 4(1):12-19.

Anas, Aswar, and Nilam Permatasari Munir. 2016. "Pengaruh Gaya Belajar VAK Terhadap Hasil Belajar Matematika Siswa." Prosiding Seminar Nasional 2(1):233-40.

Argarini, Dian Fitri. 2018. "Analisis Pemecahan Masalah Berbasis Polya Pada Materi Perkalian Vektor Ditinjau Dari Gaya Belajar.” Jurnal Matematika Dan Pembelajaran 6(1):91-99.

Debora, Yantina. n.d. "Kisi Kisi Ters SKD SKB CPNS." Retrieved June 14, 2019 (http://www.google.com/amp/s/amp.tirto.id/kisi-kisi-soal-tes-skd-dan-skb-cpns-2019menurut-bkn-elgx).

Filayati, Novianti, and Suriyah. 2019. "Analisis Kesalahan Siswa Dalam Memecahkan Soal Cerita Pada Materi Limas Ditinjau Dari Gaya Belajar.” JIPM 01(01):1-10.

Fitri, Nurul Wahidatul, Sri Subarinah, and Muhammad Turmuzi. 2019. "Analisis Kesalahan Newman Dalam Menyelesaikan Soal Cerita Materi Turunan Pada Siswa Kelas XII." Mandalika Mathematics and Education Journal 1(2):66-73.

Gilakjani, Abbas Pourh, and Seyedeh Masoumeh Ahmadi. 2011. "Effect of Visual, Audotory, and Kinaesthetic Learning Styles on Language Teaching." International Conference on Social Science and Humanity IPEDR 5(1):469-72.

Islamiyah, Anna Citra, Sudi Prayitno, and Amrullah. 2018. "Analisis Kesalahan Siwa SMP Pada Penyelesaian Masalah Sistem Persamaan Linier Dua Variabel." Jurnal Dikdaktik Matematika 5(1):66-76.

Ldpride. n.d. "What Are Learning Stysles." Retrieved April 5, 2020 (http://www.ldpride.net/learning styles.MI.htm).

Nafi'an, Muhammad Ilman. 2015. "Analisis Kemampuan Kognitif Siswa Dalam Memecahkan Masalah Matematika." Jurnal Pendidikan Dan Pembelajaran Matematika (JP2M) 1(1):8088.

Nurhayati, and Luvy s Zanthy. 2018. "Analisis Kemampuan Pemecahan Masalah Matematika Siswa MTs Pada Materi Pola Bilangan.” Jurnal On Education 1(2):23-30.

Nurojab, Evi Supriatna, and Veny Triyana Andika Sari. 2019. "Hubungan Self Confidence Terhadap Kemampuan Pemecahan Masalah Matematika Siswa." Jurnal Pembelajaran Matematika Inovatif (JPMI) 2(5):329-36.

Ridwan, MUhammad. 2017. "Profil Kemampuan Penalaran Matematis Siswa Ditinjau Dari Gaya Belajar." KALAMATIKA Jurnal Pendidikan Matematika 2(1):233-40.

Subarinah, Sri, Nurul Hikmah, and Syahrul Azmi. n.d. "Analysis of Student's Mathematic Investigation Based on the Variation of Mathematical Abilities." Proceedings of the 1st Annual Conference on Education and Social Sciences 465:115-18.

Sugiono. 2020. Metode Penelitian Kualitatif Edisi Ke-3. Bandung: Alfabeta.

Vidayanti, Sugiarti, and Kurniati. 2017. "Analisis Kemampuan Kognitif Siswa Kelas VIII SMP Negeri 11 Jember Ditinjau Dari Gaya Belajar Dalam Menyelesaikan Soal Pokok Bahasan Lingkaran.” Kadikma 8(1):137-44. 
Wahidmurni, Mustikawan, and Ridho. 2015. Evaluasi Pembelajaran Kompetensi Dan Praktik. Vol. 4. Yogyakarta: Nuha Litera. 